\title{
Cultura Cultura
}

José Esteves Pereira)

As paisagens do reino, os poderes do rei, os saberes dos vassalos. Mudanças e permanências

\section{António Ribeiro dos Santos (1745-1818)}

As paisagens do reino, os poderes do rei, os saberes dos vassalos. Mudanças e permanências

\section{António Camões Gouveia}

\section{(2) OpenEdition}

\section{Journals}

Edição electrónica

URL: http://journals.openedition.org/cultura/3650

DOI: $10.4000 /$ cultura.3650

ISSN: 2183-2021

Editora

Centro de História da Cultura

Edição impressa

Data de publição: 1 janeiro 2017

Paginação: 17-44

ISSN: 0870-4546

Refêrencia eletrónica

António Camões Gouveia, « António Ribeiro dos Santos (1745-1818) », Cultura [Online], vol. 36 | 2017, posto online no dia 05 setembro 2019, consultado a 06 janeiro 2020. URL : http:// journals.openedition.org/cultura/3650; DOI : 10.4000/cultura.3650

Este documento foi criado de forma automática no dia 6 janeiro 2020

(c) $\mathrm{CHAM}$ - Centro de Humanidades / Centre for the Humanities 
As paisagens do reino, os poderes do rei, os saberes dos vassalos. Mudanças e permanências

\section{António Ribeiro dos Santos (1745-1818)}

As paisagens do reino, os poderes do rei, os saberes dos vassalos. Mudanças e permanências

\section{António Camões Gouveia}

1 Os tempos conjunturais de 1745 a 1818 são evidentemente diversificados e dissonantes: nas formas de poder e nas aflorações de riqueza; na organização dos corpos sociais e nas variações de sociabilidades; nas dimensões do Reino e dos seus espaços não europeus, na sua descrição e conteúdos de narrativa; no número das suas gentes e dos seus privilégios, obrigações, fidelidades e direitos; nos tempos de divulgação do que se lê ou pode ler, se ensina, se pode ensinar e se quer aprender através das notícias das "europas"; no que se escreve, como se escreve e sobre o que se escreve; na Corte, nas Academias e nos salões.

2 A vida e actuação de António Ribeiro dos Santos é um resultado dessas vivências diversificadas e dissonantes. Alguma novidade no que se escreveu? Nenhuma. Então, o que preocupa este curto texto? Um objectivo apenas: tentar retraçar e compreender as linhas de um desenho, de componente biográfico-intelectual, em que as cores da paleta do barroco atlântico-joanino, paulatina mas persistentemente, se tornam mutáveis em luzes enciclopédicas e europeias.

3 Ao constituir-se este inquérito, composto por fragmentos esparsos e diferentemente significativos, desiguais nas autorias, meios de divulgação e destinatários, tentou-se lançar pontes. Pontes que deixem em aberto, como problema, afirmações abrangentes mas incapazes de sustentar as formas individuais de pensar e de escrever que se vêm afirmando desde a construção da autoria no Renascimento. A sua consagração aconteceu em suportes retóricos académicos, panfletários, jornalísticos, mas também poéticos e detentores da privacidade, encerrada nas composições diarísticas, memorialísticas e epistolares, que dão corpo às "escritas do eu". 
O Reino estendia-se em paisagens de senhorios e concelhos, pontuadas por uma malha crescente de espaços urbanos, de afirmação litoral exponenciada numericamente e em actividades de poder do rei, da administração ou das gentes do meio económico, em extensão atlântica e de olhadas intermitentes ou dependentes da Europa. O Porto ia crescendo, Braga, Coimbra, Elvas, Évora e Setúbal permaneciam, muitas pequenas vilas apagavam-se, e, com tudo isto, Lisboa impunha-se como macrocéfala.

Os senhorios e os concelhos eram estruturas de ocupação dos espaços de território do Reino, instrumentalizando-os institucional e politicamente. Como instituições de matriz consuetudinária que se ia tornando escrita, quer senhorios, quer concelhos, acarretavam uma persistência de memória quotidiana, o mesmo será dizer, como é evidente, de algum esquecimento. Mas quer uns, quer outros, mantiveram dimensões de poder que enleavam e limitavam no seu viver os habitantes do Reino. Enleios que, vertical e horizontalmente, se apresentavam como estruturantes das configurações sociais. Dependentes do Rei, os senhorios têm uma tutela limitativa e impositiva na Lei Mental (1434) que conduzia a formas de sucessão dos donatários consequente com os enfiteutas. Mas o poder nos senhorios detinha credibilidade simbólica/de memória e permitia, numa fórmula só constatável caso a caso, o desempenho de poderes de coerção e de jurisdição implicando o governo da terra e o arrecadamento de determinados tributos e, também, a possibilidade de apresentação de alguns oficiais. Confundindo-se com esta construção delegada pelo rei, coexistiam e misturavam-se os concelhos, de natureza e organicidade mais espartillhada, conduzidos, se não mesmo controlados, pela Coroa por meio dos seus órgãos de poder centrais.

Os mecanismos de poder (mais ou menos institucionalizados) vão sendo conhecidos e também, concomitantemente, as configurações sociais que se geram numa cadeia hierárquica sinalizável e evidente nos dois campos de poder territorial. Do mesmo modo se percepcionam nesta cadeia elos horizontais, menos constantes e menos efectivos, o que tem realidade nas pontes transversais de poder, significado e poder simbólico-social, localmente e no centro.

7 Senhores das terras e gentes da governança dos concelhos integravam um crescente manobrar da coisa pública por todo o Reino, ibérico ou atlântico e em quebra asiática um manobrar que resultava na validação e no reforço dos poderes dos Conselhos às Secretarias de Estado, reformadas em 1736 e permeáveis pelo Reino nos saberes jurídico-letrados da maioria dos corregedores e provedores, não esquecendo o aumento paulatino dos juízes de fora.

8 Que percepção e que leitura crítica, ou não, fez e tinha António Ribeiro Santos desta realidade? Podemos encontrá-la nos seus papéis e correspondência? Como foi que essa leitura pesou na estruturação das suas construções de jurista-reformador e agente de cultura? o que se lhe mostrou como particular, permanente, coerente, ultrapassável e reformável? Conseguem denotar-se respostas a estas questões na montagem teórica do seu modelo de análise e prospecção?

9 Em 24 de Maio de 1797, escrevia a D. Frei Manuel do Cenáculo a propósito de livros e de moedas, de classes, de criação de listas, de uma organização racional de conteúdos: A vista de tantas, e tão brilhantes preciozidades os olhos não se fartão; o espírito se maravilha; a razão se alarga a dilatados horizontes; a imaginação se arrebata, e se eleva sobre os astros; alevanta-se a alma acima da mesma; desperta o coração todos os seus sentimentos; solta o genio os seus voos; e os seus rasgos; e todas as potencias do espirito humano se poem em movimento e energia (Cenáculo 2014, 57). Meses depois, já em 12 de Janeiro de 1798, parece concluir: 
Agora, que tenho junta tanta riqueza, entro nos cuidados particulares do gabinete numismático, e terei de ver, e admirar miudamente tantas peças, e raridades para as classificar, e collocar ordenadamente em seu lugar, porque o publico se goze dellas (Cenáculo 2014, 70).

É interessante esta mobilidade de observação, este atento posicionamento de mudança intelectual de ideias mas também de garantia de que reformar/mudar não era um abalo radical, revolucionário. Porque as mudanças iam acontecendo à sua volta. Olhe-se o Reino de senhorios e concelhos como paisagem (cf. Teles 2003; Carapinha 1985; Carapinha 2011). Coloquem-se as gentes no território; veja-se como contar, descrever e conhecer se equilibram no desenho de um mappa do Reino.

o corpo, o sexo, a doença e a cura são o enquadramento das realidades de descrição da população dos séculos XVIII e XIX. Tendo-as como pano de fundo, pode perceber-se melhor quantos homens e mulheres, velhos, jovens e crianças podia haver no Reino. Tornam-se mais claras as relações que se estabelecem entre o número total da população, o nascimento e a mortalidade infantil ou por envelhecimento, a idade que predomina no acesso ao casamento e consequente constituição de nicho familiar e, mesmo, a escala de determinação de uma situação de velhice. Em paralelo é importante determinar como se equilibram ou desequilibram as relações entre os dois sexos, entre a saúde e as práticas médico-farmacopeias, encastradas nos saberes livrescos da Universidade e em curandices ancestrais. Variantes descritivas da população são as bases das paisagens rurais e urbanas, da aproximação aos grupos de topo social linhagístico e aos de base, nas suas relações familiares de afirmação ou de subsistência. Ao tentar encontrar, mais do que contagens, as variações e discriminações populacionais do Reino para desenhar paisagens, é necessário inscrever ou sobrepor as gentes aos espaços, melhor, perceber as taxonomias espaciais dos designativos populacionais, mais uma das retóricas do discurso estratigráfico que é necessário desmontar.

Nas fontes demográficas dos séculos XVIII e XIX referem-se sucessiva, concomitante, complementar e antagonicamente, fogos, moradores, vizinhos e almas... Para acrescer as dificuldades hermenêuticas, crescem naqueles discursos de descrição demográfica quantitativa possível, mas não constituídos na sua maioria com esse fim, as cidades, vilas e lugares, os arrabaldes e os termos, as quintãs, as quintas, os casais e as herdades, e também coutos, honras e isentos, mosteiros e conventos, paróquias e freguesias, dioceses e províncias religiosas... numa teia de designativos de variação geográfica, dimensão e tutelas de poder institucional.

13 A demografia histórica é, por isso, inseparável das delimitações administrativas, quer de utilização consuetudinária, quer de ordem régia, senhorial, concelhia, diocesana ou congreganista; ao mesmo tempo, é refém das suas indefinições fronteiriças e sobreposições constantes.

No século XVIII de Ribeiro Santos, o Reino estava dividido em seis províncias (Minho, Trás-os-Montes, Beira, Estremadura, Alentejo e Algarve), 43 comarcas, cerca de 841 concelhos e um número alargado de quase 4000 freguesias. As dioceses eram, em 1774, em número de 19 e as variadas, e em constantes subdivisões, províncias de religiosos são de conto difícil (Fonseca 2000).

15 Todas estas divisões do espaço e, por aí, das gentes que o habitam, hierarquizadas socialmente como privilegiados, não privilegiados e "quase" privilegiados ou passíveis de o virem a ser, têm territorialidades com áreas muito diferentes, não só dentro de cada uma das possibilidades de gestão administrativa, como entre o Norte e o Sul, o 
litoral e o interior. Daí decorre, desde logo, que esta assimetria espacial tenha paralela correspondência no número de efectivos populacionais, assim como (basta pensar na tutela administrativa de qualquer uma delas e nas características geoeconómicas que as distinguem) nos níveis de rendimento e das possíveis incorporações de trabalho.

No século XVIII o Reino aparece povoado num crescendo que vai da avaliação do clérigo regular teatino D. Luís Caetano de Lima na sua Geographia de todos os estados soberanos de europa... de 1735, onde afirma a existência de 2300000 habitantes (Lima 1735), passando pela Contagem (1776) de Pina Manique, com 633432 fogos (o que, multiplicado por um coeficiente 4, permite a Veríssimo Serrão ${ }^{1}$ apontar para 2533728 habitantes), pelo Censo (1798), também ordenado por Pina Manique, que faz um levantamento de 746456 fogos (ou seja, 2987456 habitantes), e pelo levantamento da população (1801) de D. Rodrigo de Sousa Coutinho e de José António de Sá Pina, que atira para 758500 fogos e para 3034000 habitantes por cálculo.

Um Reino desigualmente povoado e administrativamente cartografado dava conta de contínuas sobreposições de poderes e, olhando analiticamente os surtos de migração para espaços urbanos do litoral, mormente Lisboa, esta é uma realidade estrutural e estruturante. Foi Vitorino Magalhães Godinho quem considerou e afirmou Portugal como um Reino fortemente urbanizado, de acordo com os padrões do Antigo Regime. A população urbana pode ir até aos $18 \%$ da totalidade do Reino. Os aglomerados urbanos engrossam, em prejuízo dos espaços rurais ou dos pequenos centros urbanizados, vilas e aldeias, do interior rural e não atlântico. As províncias perderam muitas gentes para Lisboa e Porto, podendo constatar-se um crescimento ao longo do século XVIII de cerca de $56 \%$ na primeira cidade e de $148 \%$ na segunda, sem que esta alguma vez alcançasse a taxa populacional da primeira. Se Lisboa e o Porto ganham uma clara dianteira numérica, o crescimento de Braga, Coimbra, Elvas e Setúbal, logo seguido do de Tavira e de Viana do Castelo, permanece e assegura as suas centralidades regionais que acarretam e se sustentam numa multiplicação de actividades económicas que necessitam de um crescimento da mão-de-obra braçal muitas vezes deficitária.

Os valores numéricos da população do "império", com o Brasil à cabeça, são pouco quantificáveis e determináveis, por dificuldades que vão da definição dos estatutos sociais em presença, longe da orgânica habitual do Reino, e na percepção de migrantes, população autóctone e ainda, flutuante e não despicienda, a população escrava e forra com origem em África. Este desconhecimento é parte a reter e dá conta da desconfiança do centro ibérico em relação aos outros centros de poder, administração, arrecadamento tributário, conquista e exploração de territórios larguíssimos, ricos e produtivos, indispensáveis à economia do Reino e ao equilíbrio da sua balança de pagamentos, mas que sociopoliticamente são desconsiderados, ou pouco considerados, enquanto factores de caracterização das paisagens. Será que essa dimensão de esquecimento reflexivo, que algumas medidas paulatinas parecem não querer deixar de mudar, toca a prática de pensar de António Ribeiro dos Santos no seu caminho para as Luzes?

Instalar estes quantitativos populacionais no território, mais ou menos urbanizado e maioritariamente de extensão rural, visualizar o litoral costeiro, os montes das Beiras, as escarpas de Trás-os-Montes, a planície do Alentejo e a orla plana ou alteada do Algarve, foi tarefa que sob diferentes roupagens e linguagens foi suportando, ao longo da época moderna, dos séculos XVI ao XIX, todo um percurso gerador de domínio político do território e envolvendo uma disciplina cartográfica crescente (Silva 1998). 
20 As bases dos roteiros e da cartografia de litorais mareáveis serviam de suporte a este saber crescente. Desenhar e determinar distâncias, inscrever na sua descrição visual, reinos, povos, animais e árvores ou referências a promontórios permitiu criar uma escola de arranque mediterrânico, constituída por famílias de cartógrafos e iluminadores dos territórios descritos. Pelos anos 40 do século XVIII, quando nascia António Ribeiro dos Santos, e até 1750, construiu-se cartograficamente o território sul do Brasil numa operação de saber académico visualizado em mapas de afirmação de poder do Rei D. João V, em prejuízo dos efectivos dos aldeamentos jesuítas e das pretendidas e mal definidas fronteiras do Reino da América com Espanha. Foi com uma argumentação cartográfica que, no Tratado de Madrid ou dos Limites, o seu diplomata negociador e cartógrafo "putativo" Alexandre de Gusmão fez a validação da posse e negociou em Madrid fronteiras que, depois, no terreno americano, tantas e tão prolongadas dificuldades tiveram para se afirmar. Num trabalho de investigação, interpretação e compreensão notável por parte de Jaime Cortesão, com o título Alexandre de Gusmão e o Tratado de Madrid, e publicado em 1952 e 1956 no Rio de Janeiro, o autor reserva a este tema toda a IV Parte ("Os antecedentes próximos do Tratado de Madrid") e a V Parte ("Trabalhos e negociações do Tratado"). ${ }^{2} \mathrm{Na}$ sua magistralidade de saber, escreveu Jaime Cortesão:

O rei e as classes cultas acordam para o estudo da geografia, da cartografia e, por consequência, também da astronomia. Que os problemas de soberania, a que aludimos, e o desejo de afirmá-la sobre novos, vastos e ricos territórios estejam na base desse renascimento, não há como negá-lo. (...). Em sessão da Academia, de 9 de Outubro de 1721, (...) Manuel de Azevedo Fortes, que vai ser a alma e a voz do renascimento cartográfico, denunciava aos seus pares que Portugal era o único reino da Europa, "que se acha sem cartas particulares (topográficas), sendo o primeiro que a todos mais ensinou a geografia e a navegação". (Cortesão 1984, 336)

Recuperando estas linhas de atitudes politico-técnicas, no final do século XVIII, vão desenhar-se espaços cada vez mais correctos e fidedignos da leitura que permitem do Reino. As fronteiras serão mais precisas, dominando-se e percebendo-se melhor as implicações cartográficas da longitude de que se faz uso. 0 relevo e os rios, as cidades e as vilas, as províncias, as comarcas e os concelhos, as separações da raia com Espanha e as fortificações que garantem a sua defesa, as estradas e mesmo os itinerários de circulação de pessoas e mercadorias, os portos e algumas pontes, são sugeridos ou grafados em mapas, ganhando alguns deles honras de impressão. De forma significativa perdem-se algumas fronteiras, ou não chegam a fixar-se. Assim acontece com as das províncias das ordens religiosas, que por vezes, muitas vezes, são esquecidas. A malha do privilégio administrativo perde uma evidência de utilidade e de razão de ser, mas vai ter de se esperar pela consagração espacial liberal de concelhos, comarcas e províncias para que seja anulada, não nos mapas, mas nas práticas diárias de poder.

Nos anos de 1745, 1746, 1747, 1748 e 1758, em Lisboa, na oficina de Miguel Manescal da Costa, saem impressas as Partes I a V do Mappa de Portugal Antigo e Moderno, uma construção literária saída da mão do padre da Patriarcal João Baptista de Castro; mais tarde, em 1762 e 1763, voltam a ser impressas (Nesta segunda ediçaõ revisto, e augmentado pelo seu mesmo Author), desta vez em três tomos, e já na Oficina Patriarcal de Francisco Luiz Ameno. Estes volumes são enormes complexos de páginas, divididos em capítulos entremeados por alguns artísticos florões e letras capitulares de qualidade artísticotipográfica; a mancha é compacta mas com parágrafos muitas vezes numerados e com início numa palavra ressaltada em itálico e continuados em tipo redondo; proliferam 
mapas, esquemas de grandes chavetas, tábuas, quadros e muitas listagens enumerativas e quantitativas, notas de rodapé de erudição em que uma auctoritas valida os conteúdos. o Mappa procura descrever o Reino em algumas das suas faces - das províncias às comarcas, destas a vilas e cidades -, com cronologias e descrições sucintas. Mais uma vez, de forma expectável, o título de cada volume, que também é uma Parte, sistematiza-a em analítica académica.

Tal didascália deixa-nos traçar o perfil geográfico-político deste Mappa corográfico. Uma vez agrupada de forma compactada e discursiva, permite uma leitura clara:

[parte I - 1745] Comprehende a situação, etymologia, e clima do reino; memoria de algumas povoações que se extinguiram; descripção circular; divisão antiga e moderna, montes, rios, caldas, fertilidade, mineraes, moedas, lingua, genio e costumes portuguezes.

[Parte II - 1746] Contém a origem e situação dos primeiros povoadores da Lusitania; entrada e dominio dos Fenices, Carthaginezes, Romanos, Godos, e Mouros; ereç̧ão da monarchia portugueza, e as principaes acções de seus augustos monarchas, rainhas, principes, e infantes; governo da Casa Real; e outras noticias politicas.

[Parte III - 1747] Tracta do estabelecimento e progressos da religião em Portugal; das ordens militares que n'elle existem, e das que se extinguiram; de todas as ordens religiosas e mais congregações; com a expressão dos conventos e mosteiros que tem cada uma, e annos de suas fundações; pontifices e cardeaes portuguezes; varões insignes em sanctidade e vistude; reliquias notaveis; e imagens milagrosas. [Parte IV - 1748] Mostra a origem das letras e universidades n'este reino; os escriptores mais famosos que têem havido n'elle em todo o genero de litteratura; o Militar, com os presidios e forças de mar e terra; os varões mais insignes em armas; e algumas victorias assignaladas, que os portuguezes têem alcançado de varias nações.

[Parte V - 1758] Recopila em taboas topographicas as principaes povoações da provincia da Extremadura; e descreve as partes mais notaveis da cidade de Lisboa, antes e depois do grande terremoto.

Terão sido casuais, fortuitos ou intencionais os inícios determinativos de cada Parte? Ou são essas palavras integrantes de um léxico retórico académico? Ao utilizar as palavras Comprehende, Contém, Tracta, Mostra e Recopila, que na segunda edição pela redução a três tomos mantém Trata e Recopila, não está a desenhar-se uma metodologia e uma perspectivação? O título da obra não a anuncia já, ao evidenciar o Antigo e o Moderno? Atente-se que é uma descrição com autorização de base no Antigo, lendário, cronístico, de narração oral de "tradição", que se recopila e que permite percepcionar o que ali se mostra... num tom pensado, que se comprehende pelos que a ela acedem, nichos de público circunscritos, e que contém, organizando, os assuntos que o título já revela e que Baptista de Castro tracta naquelas centenas de páginas.

Se as palavras não nos enganam, caso a intencionalidade se verifique ou o vocabulário académico o justifique, a leitura dos assuntos citados na acumulação dos títulos ainda nos leva mais longe cruzando as duas edições.

Em 1699, 1723-1726, 1765-1767, 1778-1779 e 1794, viajam por Lisboa e pelo Reino, respectivamente, o padre franciscano capuchinho francês François de Tours (Tours 1989, 47-53), o naturalista e botânico Charles Fréderic de Merveilleux (Merveilleux 1983, 129-257), o militar, aventureiro e talvez espião italiano Giuseppe Gorani (Gorani 1989), o militar escocês Arthur William Costigan (Costigan 1989) e William Beckford (Beckford 1997), um parlamentar inglês e rico proprietário na Jamaica. Com diferentes formações e com objectivos diferentes, estes são alguns dos autores que deixaram 
descritas as suas viagens, cheias de ideias preconcebidas e de mitos em voga sobre Portugal, mas também, em tom de diário, de informações sobre o dia-a-dia.

Os seus olhares de observação caem, todos eles, em lugares repetidos de realidades da viagem e de acontecimentos que se particularizam nos seus casos pessoais. Avançando por itinerários, conduzidos por almocreves ou outros; percorrendo caminhos a pé, em montada ou de carroça, berlinda, seges ou carruagens, deixando a tracção a muares, asininos e equinos; atravessando rios e ribeiras por algumas pontes e em barcaças; todos eles se queixam da qualidade das "estradas" e dos meios de transporte. As paragens para descanso e alimentação de homens e animais fazem-se em estalagens e hospedarias de fraca qualidade, higiene reduzida, alimentos parcos, gordos e mal cozinhados... um Reino pobre, iletrado, rural e sem diferenças de qualidade é a conclusão mais ou menos acentuada por todos eles.

Descrições botânicas, fortificações, gentes e hábitos estranhos, rurais ou de excessiva devoção religiosa, maus caminhos e estalagens, são muitas as curiosidades que se descre- vem e se repetem ou se observam com cuidado. Curiosidade e, também, muita perplexidade e espanto perante o real. Perdida nos seus muitos e complexos escritos e edições, William Beckford conta uma pequena história de viagem que data de 1794 . Nesse ano o autor terá visitado e olhado as gravuras de James Murphy, ou, simplesmente olhado as gravuras da Batalha... (Neto 1997). Segundo nos conta, a viagem foi preparada e enquadrada por poderes eclesiásticos e senhoriais que facilitaram e deram qualidade à deslocação: "avançaríamos, ou melhor, rastejaríamos por curtas e suaves etapas, com paragens para almoçar, jantar e repousar, tão deleitadamente como na mais cómoda das casas" (Beckford 1997, 18). Mas logo se revela uma outra face,

para sossego e talvez por desinteresse, dos meus aristocratas eclesiásticos companheiros, os comentários topográficos seriam completamente banidos, e nenhuma pergunta seria feita sobre quem doou esta igreja ou construiu aquele palácio! (Ibidem)

Notas que dão que pensar... Volte-se à viagem... Idílica, os badalos das nossas mulas soavam alegremente e os cocheiros cantavam em coro (Ibidem), quando, inesperada e acidentadamente:

a escassas duas milhas das Caldas, o campo espraiou-se à nossa frente, sem traçado visível de estrada para as pesadas carruagens que nos atravancavam. Ao tentarmos prosseguir, ficámos logo atolados (...). Os meus reverendos companheiros (...) decidiram chamar a posse comitatus em nosso auxílio. Foi enviado um emissário a uma aldeia vizinha. (...). o mensageiro regressou pouco depois, acompanhado de um magistrado muito eficiente e de trinta ou quarenta camponeses. (Ibidem, 35)

Um espanto, uma perplexidade, posse comitatus? O que quis Beckford encerrar neste "latinismo" arcaico senão isso mesmo? Como é que ainda há no território do Reino onde se viaja poderes como estes de uns sobre outros? Como é que se podem exigir direitos aos vassalos com base em elos ancestrais e mal legislados? Como é que se confundem exercícios de poderes consuetudinários com os de um magistrado? Um reino curioso e cheio de permanências?

Os espaços e os poderes no Reino. Os espaços percorridos pelos viajantes são limitados. O caminho do Alentejo, da fronteira de Elvas a Estremoz, daqui a Arraiolos, Montemor, Venda do Duque (Vendas Novas), Aldeia Galega (Montijo), daí a Lisboa de barco. 0 mar e os portos litorais pesam; Lisboa, Setúbal, Porto, Viana do Castelo, Vila Real de Santo António e Tavira vão merecer as preferências. Mas Lisboa acima de tudo e em tudo. 

de Miguel Manescal da Costa, Impressor do Santo Ofício, um texto que já havia sido incluído no Mappa de Portugal, anos antes. A reedição dá conta de uma necessidade útil: guiar os que por Portugal viajam e que por ele se querem aventurar. $O$ livro intitula-se Roteiro terrestre de Portugal em que se ensinaõ por jornadas, e summarios naõ só os caminhos, $e$ as distancias, que ha de Lisboa para as principaes terras das Provincias deste Reino, mas as derrotas por travessia de humas e outras povoações dele. No texto introdutório, além de aduzir referentes de memória justificativa do século XVII ao Padre Carvalho da Costa, Baptista de Castro tem o cuidado de explicar a centralidade de Lisboa e a importância e utilidade do Roteiro:

O ponto central, que elegi para delle lançar os Roteiros para as mais partes, pareceo-me ser adequado, e util para clareza, Lisboa; como Corte do Reino Portuguez, he o coração da sua Monarquia, não tanto pela ventajem do felicissimo sitio, em que está, quanto pela grande capacidade e conveniencia do commercio, que tem; onde à maneira dos coração nos corpos viventes, que he o principal fundamento, que vivifica todos os seus membros, assim Lisboa com huma facil, e contínua distribuição communica, e reparte a substancia vital dos cabedaes a todas as partes mais remotas das suas Comarcas; ou jà pelas veas dos portos, e trajectos dos rios, ou pelas vias das estradas, por meio das quaes recebe tambem com reciproca affluencia a fertilidade, e regalo dos frutos, que todas as terras deste Continente lhe estão tributando como a Princeza. (Castro 1768, 7-8)

Sem confusões, mas num ritmo binário académico-ilustrado, afirma-se aqui a mítica de Lisboa como Corte, e por aí coração do poder que se exerce na estrutura físicoadministrativa das Comarcas; também não se perdem os tópicos ancestrais da ventajem do felicissimo sitio, a que se acrescenta, valorizando, a riqueza e grande capacidade $e$ conveniencia do commercio, que tem. Se esta centralidade é a razão de Lisboa ser o início dos Roteiros outra ainda há: a que tem a ver com a comunicação, o andar o Reino pelas veas dos portos, e trajectos dos rios, ou pelas vias das estradas. Um programa, Roteiros impressos, contributos para um outro conhecimento? Possibilidade de novas práticas de actuação territorial? Simples Roteiros para viajantes curiosos? Apesar de tudo um denotar de uma diferença no olhar para o território e suas paisagens.

Que sabia e como sabia ou conhecia Ribeiro dos Santos o Reino, das gentes e dos seus costumes que extravasavam os textos corográficos, académicos e eruditos? Teria uma observação tão superficial quanto a dos viajantes em percursos, em itinerários, pelo Reino que ele próprio pudesse ter feito, tal como registado por Baptista de Castro? Como conheceria estes textos corográficos? Apenas como homem dos livros e seu organizador? Apenas como peças de uma classificação de bibliotecário? Ou interessarlhe-iam os conteúdos e preocupá-lo-iam os meios, ainda que só legislativos, de os pôr em prática ou corrigir?

António Ribeiro dos Santos, como muitos dos homens com proximidade legislativa e intelectual ao poder, terá tido de visionar, delimitar e distinguir, não só as fronteiras internas do Reino administrativo como o resultado para os seus habitantes dessas sobreposições de fronteiras da coroa, dos senhores, dos concelhos, das diferentes corporações religiosas. Mas, ao mesmo tempo, vivia um tempo de construção de um sistema de denotação e de apropriação virtual do espaço que se configurou em cartas geográficas fiáveis. Ainda nesse sentido foi dotado, em redor do seu meio académico, de uma analítica corográfica, variável nos campos descritivos e na fiabilidade das recolhas, mas capaz de, caso a caso, determinar essas pequenas fronteiras e perceber 
temporalmente a estratigrafia territorial do poder. É clara a criação de um corpo de detentores de saber nas formas de descrever com uma linguagem própria e não literária, ou pelo menos literário-científica, que se concretizou em torno de riscadores e gravadores (Brigola 2003, 248 n. 41, 260 n. 74, 263 n. 82). Esta criação de actividades técnicas e de sistemática formal, que retirou a descrição do reino aos viajantes, doravante olhados como "literatura de viagem", e a colocou nas mãos destes pequenos oficiais creditados pela Coroa, possibilitou as recolhas que resultam num corpus autónomo e válido na captação do Reino, tal como a produção corográfica de que Ribeiro dos Santos acabou por ser parceiro.

37 A questão de fundo não se deve colocar nas impossibilidades de António Ribeiro dos Santos avaliar e conhecer o diagnóstico do Reino, mas sim, na inexistência de meios que conduzissem, fielmente, ao desenvolvimento do seu enciclopedismo prático das Luzes como forma de pensar o Reino e, ao mesmo tempo, de nele intervir para o reconfigurar económica e politicamente em bases não reformistas de continuidade mas "revolucionárias". Os suportes de interpretação estão condicionados, na sua originalidade de diferença afirmativa, pelos sistemas que os circunscrevem. Linguagens, mediações, conteúdos e preocupações são as dos mundos académicos, também elas muito variadas, mas tuteladas e conducentes a retóricas de saber e de leitura centradas numa visão de observação política de cariz regalista absoluto do Barroco atlântico.

Não se notará tanto esta distância entre possibilidades e aplicações no campo da discussão de ideias, limites e sistemas de razão por ser pautada e inscrita em espaços de grupos intelectualizados e de observação de gabinete (mesmo salão ou café), sem prática política implícita ou recorrente. Lembre-se que esta actuação de ideias de renovação tem o seu primeiro momento na reforma de 1772 da Universidade de Coimbra, quando, deixando de lado as construções tardo-medievais de segunda escolástica, ainda que renovadas, se avançou para uma constelação de saberes, não já a descrever aquela órbita mas uma nova e com novo epicentro: a da razão, visível, em primeiro lugar, nas experiências de filosofia natural em distância assumida para evitar colisões com as teologias e seus resultados em discursos ocos de retóricas sem significado e explicação quantificável e dedutível, apenas exercício de palavras.

o percurso lento do avanço dos ditos "conhecimentos úteis" como forma de crescimento do poder dos saberes das Luzes é uma evidência (cfr. Nunues 2001). Mas é lento... Os engenheiros militares das academias e empreitadas joaninas, ou Manuel de Azevedo Fortes, Bento de Moura Portugal, Bartolomeu e Alexandre de Gusmão, são nomes evidentes e desconexos desse percurso que se cruzará, a par de outras lógicas de saber e de conjuntura de poder da Academia das Ciências, do duque de Lafões ou do abade Correia da Serra, com os núcleos de poder-útil dos reformadores Domingos Vandelli, Della Bella ou Ribeiro Sanches, entre outros.

Conhecimentos úteis, cartografias, estruturas de engenharia de edificação, pensamento matemático, higienista e médico, são um peso de saberes das artes e das "ciências" do Barroco das Luzes (Araújo 2003, 23-50). Como se aproximou António Ribeiro dos sábios destes saberes? Será que a sua existência e realidade especulativa teve impacto na sua legislação e "suas" bibliotecas? E importariam estas "utilidades", tal como eram explicita- das, para o saber económico e político?

41 Um Almanach de 1731, com previsão para o anno de 1732, bissexto (Coura 1731). Um autor, Inocêncio Fernandes de Coura, um quase-anónimo, do qual pouco mais se sabe além do 
nome. Uma edição pela oficina de António Pedroso Galrão, que detinha uma actividade socioprofissional familiar na Lisboa Ocidental, repartição urbana gerada pela erecção da Capela Real de D. João V em Patriarcal, cardinalato e sede de diocese!

Entre as páginas 33 e 36, apresenta-se um "método" da agricultura. Logo no prólogo desse curto texto pôde escrever-se:

Há muitos que se aplicam com grande curiosidade à agricultura, estes como desejam acertar, perguntam e indagam algumas coisas aos mais experimentados, que muitas vezes lhe não participam o que sabem, para pois os desenganar, industriando-os, serve este método que se escreve copiado dos melhores autores que ensinam que ... (Coura 1731, 33).

Depois, usando o calendário como narrativa (como sistema?, como método?), vão declinar-se os produtos e actividades agrícolas que deverão realizar-se na crescente e na minguante. Enxertar, semear, podar, limpar, dispor, ampar, plantar, cevar, mondar, estacar, desfolhar, segar, crestar, tosquiar, ceifar, colher, arrancar, cortar, vindimar, escavar, abrir covas, cobrir, pôr, escavar, lavrar, estercar, levantar valadas, matar, ... são os verbos que dão conta das acções de um ano agrícola que se quer aprender e que se misturam com frutas, árvores, cereais, primores de horta, animais de capoeira, abelhas, ovelhas e porcos. Um "método"? Será? Ou o enumerar impresso daquilo que os mais experimentados sabem e guardam, não partilham ou, mais correcto, não publicitam? Um enumerar cronológico, de Janeiro a Dezembro, de tarefas de saberfazer tornadas curiosidade pelo que se escreve nos melhores autores. 0 sistema/método de enumeração continua apegado à validação dessas auctoritas, ainda que procure ultrapassar os mais experimentados. Mudanças? Novo método? Sistemática analítica, ou mesmo, e só, linguagem inovadora? Não parece.

Claro é que, para lá dos conhecimentos úteis do Almanach, publicitação de práticas que se querem alargar ou normalizar sob a capa de aprendizagens, existem outras tópicas mais fortes no que respeita ao campo do interesse económico onde a agricultura se insere. Conhecer foi aqui, por mãos de coloração fisiocrática, concretização de conhecimentos, da flora e da consequente paisagem agro-produtiva do Reino. Para lá da curiosidade e do ensino aos que sobre ela queriam aprender, agora havia que o fazer para criar desenvolvimento e gerar lucros. Não admira que, por volta de 1800 , Joaquim Pedro Quintela, Contratador dos Tabacos e futuro barão de Quintela (1795), indague sobre o tabaco (Brigola 2003, 274 n. 119), ou que o abade Correia da Serra, D. Rodrigo de Sousa Coutinho ou Domingos Vandelli, todos nascidos e intelectualizados na segunda metade do século XVIII, se interessem pelos cultivos e potenciais económico-produtivos do linho, arroz, plantas "bravas" ou canela de Pernambuco (Brigola 2003, $277 \mathrm{n}$. 127-129, 278 n. 131). Dirigindo-se ao vice-director do Jardim Botânico da Ajuda, Rodrigues Ferreira, o homem que no poder junto do Rei intendia na Marinha, o atlantista D. Rodrigo de Sousa Coutinho, atrás referido, escreveu:

o Inspector do Arsenal Real da Marinha hade remetter para o Real Museo huns Cazulos de Aranhas que vierão do Maranhão, afim de que se a porção da tal Seda for grande, que a s.mce mande examinar se seria boa para fabrico de chapeos. Secretaria de Estado em 13 de Agosto de 1799. (Brigola 2003, 280 n. 139)

Marinha, Maranhão, jardins botânicos, museus, casulos para seda e fabrico de chapéus; todo um complexo prático de saberes e de poderes de produção. Aqui parece haver mudança. Descrição, visualização do mapa do Reino e sua viagem pelos estrangeiros, pelo não-olhar português. Divulgação de saberes úteis para os curiosos e possibilidade de melhorias técnicas com reflexo na produção agrícola. 
E outros havia que também eram viajantes. Só que procuravam avaliar o que viam e descreviam na sua viagem. A sua atitude de fundo e de método era muito diferenciada das anteriores dos estrangeiros. Neste corpo de conhecimento e de descrição dos terrenos e espécies, nesta ligação da viagem a actos de experimentação prática e metódica, de anotação, de recolha de esboços desenhados ou rascunhados em palavras, encontram-se elementos que dão conta da construção de atitudes diferentes, de olhares e mensurações de espécies, sistemas geográficos e suas implicações bem distanciadas da das Corografias. As acções assim descritas estão bem mais próximas da viagem científica que inundará o século da Encyclopédie (Darnton 2013), em que os académicos deixaram, a pouco e pouco, os seus cadeirões discursivos e se aventuraram na procura de respostas na realidade que os cercava e da qual pouco conheciam, entendiam ou explicavam (Cardoso 1997).

Foi João Brigola quem chamou a atenção para dois textos que, em conjunto, fixam de uma forma evidente toda essa mudança de atitude perante o real natural e o que significam de relação e método com a paisagem.

São seus autores Agostinho José Martins Vidigal - formado em Medicina e aluno, em História Natural e Chimica, de Vandelli, que muito o estimava; escreveu uma memória que dá pelo título de Methodo De fazer Observaçoens, e Exames para augmento da Historia Natural, com os meios de preparar, conservar, e dispor nos Museos os diversos productos da Natureza, por volta de 1783, texto que permaneceu manuscrito (Brigola 2003, 211-215) ${ }^{3}$ e José António de Sá - formado em Leis, publicista, amigo-discípulo de Vandelli, que faz sair impresso, também no ano de 1783, o Compendio de observaçoens, que fórmão o plano da Viagem Politica, e Filosofica, que deve fazer dentro da Patria (Ibidem, 215-221). Dois percursos diferentes na formação e actuação, semelhantes na proximidade a Vandelli e ao que ele significava neste campo "revolucionário" dos saberes em instalação. Um permanece desconhecido dos meios não universitários de mudança, é um texto de "carácter assumidamente escolar" (Ibidem, 212); o outro passa a letra de forma as relações de observação. São ainda diferentes no conhecimento que detemos sobre a sua actuação nas esferas do experimentar, do politizar e do economicizar os saberes sobre a natureza, numa perspectiva de História Natural. De Martins Vidigal, além do já referido, pouco se pode acrescentar. Quanto a José António de Sá, podem ainda notar-se duas dimensões que aqui interessa realçar: a sua capacidade de publicista - não é por acaso que é autor de Memorias da Academia das Ciências e constantemente referido na Gazeta de Lisboa (Ibidem, 215 n. 129) - e o seu interesse pela "economia da natureza" (Ibidem, 215), aí se devendo valorizar a larga intervenção no que respeita as amoreiras, fiação e suas consequências manufactureiras. Uma vez contidos nestes contornos biográficos, olhem-se as linhas de fundo que quanto ao objecto e método dão corpo ao Methodo e ao Compendio. As palavras dos títulos são um índice claro daquilo que João Brigola caracterizou como uma "nova tipologia narrativa distinta das anteriores", um "exercício intelectual" (Ibidem, 212). Fazer observações e fazer exames são as constituintes da atitude magna que se entende querer atingir com esta viagem política e filosófica dentro da Pátria que dá corpo à nova História Natural. Não só se altera e se especifica o método, como a finalidade da observação e da constituição deste saber. Tem-se em vista a esfera pública, não da opinião literária ou académica, mas daquelas outras que podem continuar a observação em espaço privado de saber: o Jardim, o Gabinete, o Museu. Agostinho Martins Vidigal é claro quando enuncia as acções, ou ligações, que possibilitarão, pelo preparar, conservar e dispor, expor os diversos productos 
da Natureza, nos Museos. O público ganha direitos de intervenção, de opinião de observador. As ideias expressas têm a comparticipação de todos aqueles que aceitam esta ligação da viagem de observação com a constituição da História Natural. Já em 1781, repare-se no emissor e no destinatário, em carta de 4 de Junho, Domingos Vandelli havia escrito ao abade Correia da Serra, dizendo que os alunos devem hir viajar a Serra da Estrella, Geres etc. assim teremos produções eboas memorias (in Brigola 2003, $205 \mathrm{n}$. 90). Sair do Reino, dentro da Patria, é aqui tarefa pedagógica em tudo o que concerne a atitude de viagem, no método que implica, no recolher de boas memórias. Sair. 0 gabinete em triunfo desde os tempos da primeira modernidade humanista vai deixando lugar ao território-Natureza. Em 1787 é ainda Correia da Serra quem recebe o lamento naturista e interventivo de Vandelli, ao mesmo tempo que a justificação da necessidade de enriquecer o gabinete/museu da Academia:

eu dezejaria muito acompanhar V. M.ce nas suas herborizações, q. estar assentado 8, ou 10 horas a ouvir estas opposições: com tudo procuro aliviar estas minhas saudades com persuadir alguns dos meos discipulos de sahirem por estes redores.

(...). E assim poderei enriquecer o gabinete da Academia. (Ibidem)

Para que esta viagem científica de historiadores da Natureza fosse completa, fosse metódica, orientada, objectiva e com fim público, ou seja, fosse mais que descrever, era necessário só mais um ponto qualitativo: comparar, participar das "nouvelles scientifiques" em circulação pela Europa. Ainda com essa dimensão, a Academia, Vandelli, Correia da Serra e todos os autores das Memórias preocuparam-se, de forma interna e de grupo, sem carácter de evidência internacional mas em vector de afastamento das Corografias académicas.

Nas três estruturas de captação do Reino referidas, de forma literária e de concretizações práticas, tão importantes quanto limitadas, o que há que recuperar para enquadrar, para incluir António Ribeiro dos Santos no seu tempo corográfico-científico do natural? Pouco? Apenas as percepções de permanência académica ou aqueles traços de mudança que a reforma de Pombal da Universidade veio incentivar? Se é difícil medi-lo, é menos difícil constatá-lo. Em 1789, ano em que a transformação Reino/Pátria se ia afirmando em Paris, Ribeiro dos Santos escreveu na Nota ao plano. Legislação económica:

De todas estas cinco partes, só entram, duas neste Código, quanto eu alcanço de seus títulos, que são a agricultura e a fazenda; e estas mesmas com muita diminuição e estreiteza, ao que parece, do que falarei a seu tempo. Contudo, as outras que pertencem à indústria e artes, ao comércio, e à navegação, sendo das que mais concorrem para a sustentação e riqueza do Estado, não podem deixar de se considerar como objectos próprios da legislação económica deste Código, e de merecer nele um distinto lugar pela sua importância e pela mesma influência que elas têm e terão sempre no estado da agricultura e da fazenda. (In Pereira 1983, 278)

51 A agricultura e a fazenda só aqui entrarão com muita diminuição e estreiteza. Estranho? Intencional? Assim parece. A legislação económica perspectiva-se, reforça-se, com base na indústria, artes, comércio e navegação. São estas áreas da economia de envolvência que não podem deixar de se considerar, e são estas que têm influência no estado da agricultura e da fazenda. Há aqui uma inversão de tópicos e uma leitura de interdependência de método fisiocrático. O Reino é o mesmo, a agricultura e a fazenda são os mesmos... mas o método de ler e construir economia, que o Código quer denotar, está em mudança, em caminho de mudança, em viagem de ideias e de práticas. 
inerários que são estradas. Descrever que é fazer História Natural. Codificar a economia, ler o espaço e as suas actividades produtivas, entender como seus motores aquilo que respeita à agricultura, mas não o conteúdo agrícola. Muitos métodos novos, muitas possibilidades de mudança.

o novo método de olhar e actuar politicamente comporta diferenças de desestabilização das práticas jurídicas e sociopolíticas. A Nação que se quer visitar para descrever não é o Reino em que os que se sujeitavam a tantos diferentes poderes eram vassalos do Rei. A Nação perfila os vassalos perante leis de igualdade individual, e não, como a Coroa/Rei fazia, perante uma diversidade de privilégios de desigualdade, corporativos ou pessoais. Reencontrar o espaço com os homens, aqueles vassalos, amanhã próximo, cidadãos; fazer da paisagem resultante um espaço político de Nação, de edificação de poderes e construção que importa soerguer foi o que o Código, e todas as suas polémicas, despoletou e concretizou. Não admira, pois, que todas as gentes urbanas de intelecto, capazes do manuseamento da palavra, da aplicação das normas, da codificação de exemplaridades e de desregramentos e fugas, tenham presentes os conteúdos e implicações do caracterizar e do declinar enumerativamente de uma palavra e suas configurações sociais: vassalos. Vassalos, direitos dos povos, poderes do Rei misturavam-se com uma facilidade implicativa que indicava novos rumos nas bases sociais ancestrais. moldura de "tradição"? em atitude de reforma não revolucionária?... da realidade do poder não questionável do Rei:

0 respeito e veneração dos reis não se deve nem pode jamais fundar solidamente sobre a ruína ou diminuição dos direitos dos povos; o verdadeiro respeito do trono consiste em que os vassalos estejam certos de que o príncipe lhes não quer fazer injustiça e lhes deixa salvos todos os meios possíveis e prontos, por que possam requerer mui facilmente os seus direitos. Esta é a base do respeito devido ao príncipe; tudo o que concorre para firmar esta base concorre para aumentar e segurar constantemente a veneração que os povos devem ao seu monarca. (In Pereira 1983, 326)

Depois, em expressão feliz e clara de José Esteves Pereira, "apelando mais para a figura do cidadão, para a do vassalo em geral, que para a do vassalo 'tout-court", regista e dá conta de que a "mutação de natureza semântica enquadra-se, assim, numa hipótese de reforma, que incluía novas formas de relação jurídica e política, estribadas num desenho arquetípico que se pensava ajustado à realidade sociológica, natural, do ser da Nação" (Pereira 1983, 258). Uma "mutação", "novas formas de relação", o "ser da Nação", não do Reino.

Voltando ao tema pela escrita explicativa e normativa de António Ribeiro dos Santos, pode ler-se:

No título I deste Código se enunciam certos e determinados direitos que competem aos vassalos: mas olhando para os títulos desta obra, persuado-me: $1^{\circ}$ que os vassalos se consideravam nela um ponto de vista, isto é, como particulares e não como corpo da Nação; $2^{\circ}$ que só se tratou dos direitos que tem cada um deles em particular, em razão dos seus serviços feitos à Coroa, e não dos que têm todos os vassalos em geral, em razão das leis fundamentais, estilos, foros, usos e costumes dos nossos reinos. (In Pereira 1983, 258)

Num sinuoso caminho entre o particular dos serviços à Coroa e um geral onde se enquadram leis fundamentais, estilos, foros, usos e costumes, nota-se a proposta de uma mutação das formas de relação jurídicas e políticas em que se diz, ou quer dizer?, 
cidadão por vassalo, em que as mutações que se referiram irão implicitamente conduzir a uma Nação, como campo semântico do pensar e do actuar político-jurídico e de cultura.

Por isso não se estranhe que todo o final de setecentos, desde quase início da sua segunda metade, viva de forma especulativa, política e interventiva a necessidade das aprendizagens. A escolarização da diferença, isto é, o romper com as estruturas formativas formais, académicas e universitárias, está na mira de todos aqueles que vislumbram outras formas de razão, de experiência não-livresca e de autoridades... A reforma dos estudos elementares/menores só se ensaia com a expulsão da Companhia de Jesus e concretiza, em algumas dimensões, com a política de mestres-escolas dos anos finais de D. José I e nos iniciais de D. Maria I (Gomes 1989). A Universidade toca a rebate com a extinção, também em 1759, do Colégio do Espírito Santo dos Jesuítas que havia sido erigido em Universidade, em Évora. Mas a reforma, aquela procura da escolarização da diferença, só acontecerá em 1772, pela própria mão do Marquês de Pombal, na sua emblemática deslocação a Coimbra.

Também aqui os dois ritmos de fundo são detectáveis nos seus barulhos de afloração. No longo século XVIII as propostas sucederam-se, de formulação crítica mais ou menos informada, de características mais ou menos radicais... Entre todas estas propostas, sobressai a do oratoriano Luís António Verney, na senda do Teatro crítico universal (1726-1739) do beneditino galego Benito Feijoo (1676-1764). A proposta crítica foi desenhada ao longo dos volumes do seu Verdadeiro método de estudar, para ser util à Republica, e à Igreja: proporcionado ao estilo e necesidade de Portugal. Exposto em varias cartas, escritas pelo R. P. ${ }^{* * *}$ Barbadinho da Congregasam de Italia, ao R.P. ${ }^{* * *}$ Doutor na Universidade de Coimbra, com edição na oficina de António Balle, em Valência, em 1746, um ano antes de António Ribeiro dos Santos ter nascido em Massarelos (Andrade 1966).

O livro tem uma estrutura interna simples e muito habitual. Um conjunto de 16 Cartas, que são pequenos tratados de crítica aos erros da educação em Portugal e de apresentação de soluções prospectivas. 0 seu género é declarativo em toda a extensão, o presumível diálogo é formal, mas há inovação nas matérias a ensinar, nos métodos a praticar e nas autoridades de aproximação a matérias e métodos. As Cartas dão conta de uma determinada diversidade enciclopédica, abordando a língua portuguesa, a gramática latina, a latinidade, o grego e o hebraico, a retórica, a poesia, a filosofia, a metafísica, a física, a ética, a cultura médica, a cultura jurídica, a cultura teológica, a cultura canonista e os estudos elementares (Verney 1949).

61 Na Carta Décima Sexta tocam-se os conteúdos pedagógico-formativos que devem acontecer nos Estudos Elementares (Ibidem, v. V: 47-148).

Os estudos, para serem regulados, devem começar desde o tempo que os meninos começam a ler e escrever (...). Já se sabe que lhes devem ensinar os elementos da Fé (...). Mais com boa vontade, que com rigorosos castigos (...). Que deve começar aos sete anos (...). Que escreva facilmente e correctamente (...). Depois, ensinar-lhe as quatro primeiras operações de Aritmética, que são necessárias em todos os usos da vida (...). Supondo, pois, que os meninos sabem ler e escrever, apontarei a V. P. o modo de regular os estudos públicos (...). Deve haver em todos os Colégios e Universidades públicas, primeira escola em que se ensine a Língua Portuguesa (...). Nisto há grande descuido em Portugal, achando-se muita gente, não digo ínfima, mas que veste camisa lavada, que não sabe ler, nem escrever (...). Privam-se estes homens do maior divertimento que pode ter um homem quando está só, que é divertir-se com o seu livro. Fazem-se escravos de todos os outros, pois, para ajustar contas, conservar correspondências, dependem dos mais. Fora de Portugal, vive-se 
de outra sorte: são tão raros os plebeus que não saibam escrever, como aqui os que sabem. O mochila, o carniceiro, o sapateiro, todos se divertem com os seus livros.

(Ibidem, v. V: 49-51) da autoridade de disciplinamento dos saberes e sua educação retirada à máquina eclesiástico-inquisitorial, e onde se enquadram a tutela livreira pela Real Mesa Censória ou estes mesmos estudos de primeiras letras, tem uma intenção política. Nela é evidente a quebra de poder catequético sobre os vassalos e a procura do seu crescimento para a cidadania na Nação. Verney mostra cuidado com o ensino da Fé, mas escreve-o como afirmação de um hábito, pode ser que bom, não se duvida, mas hábito; já se sabe que lhes devem ensinar os elementos da Fé, e logo de seguida explicita e integra, digo, as coisas mais principais: acostumá-los a obedecer e serem corteses, etc. (Verney 1949, v. V 49). Integra ou submerge? A cortesia, por mais polícia cristã que seja e por mais capacidade de criação de modelos educativos e de educadores hagiográficocorteses no pós-Trento, nunca será moral, nem devocionária, nem litúrgica, nem sacramental; ou seja, nunca será catequética. E a catequese, desde as Cartilhas de ler e escrever dos Humanistas, será sempre o suporte, limitado, ininterrupto, de qualidade muito questionável e desigual mas possível e obrigatório que suporta grande parte das operações de ensino elementar, primeiras letras/doutrina cristã (Gouveia 1998). Ora, esta dimensão, ou é integrada, ou submersa, ou dilui-se, ou, mesmo, perde-se, por abandono de implicação pedagógica. Como escreveu Verney, é algo que já se sabe que lhe devem ensinar (Verney 1949, v. V: 49).

Já com idade madura, entre os 47 e 49 anos, em 1792-1794, António Ribeiro dos Santos constrói os interessantes Estatutos das Reaes Escolas de S. Vicente de Fora. Aí tudo se entrelaça: Polícia, cortezia, comedimento, compostura, decencia, educação ingenua, liberal e digna e o homem christão e cidadão. Um texto que deixa bem claro este balancear de época e do homem de fazer política de cultura que foi António Ribeiro dos Santos. Importa ler esta passagem de síntese:

Terão muito cuidado que a disciplina e polícia das aulas se guarde constantemente entre todos, e que nas lições, exercícios e actos destas escolas e em toda a conversação e trato entre si e com os seos superiores se hajão sempre com muita cortezia, comedimento, compostura, e decencia, e se costumem em todas as suas palavras, acções e maneiras simples elegancia de huma educação ingenua, liberal e digna do homem christão e cidadão. (Pereira 1983, 65)

Mas este homem christão e cidadão, onde pode aprender para se construir? E com quem? E o que pode aprender? Há casos que dão conta de todo o processo de avanço das aprendizagens capazes de criar estados sociais de desempenho de saberes e com prática dos mesmos. Em todos eles, não são muitos os estudados, o que se encontra é a criação de institutos de saber não formal, não escolar, mas que, na retórica académica, na conversa decalcada da sociedade cortesã de salão e na diatribe da rua ou do café, se irão consolidar entre os finais de setecentos e inícios de oitocentos.

Um caso de assinalar é o dos já referidos engenheiros-militares (Cortesão 1984, 349-383; Moreira 1989). O ponto de partida é o da segunda modernidade, a Guerra da Restauração. Seguindo a síntese de Rafael Moreira, sabemos que estes engenheiros são, desde então, protegidos nos seus saberes quando estes são institucionalizados por uma Junta de Fortificação que se faz funcionar anexa ao Conselho de Guerra, o que se reforça com a criação da Aula de Fortificação, pelo ano de 1642, no Paço da Ribeira e, depois, na Ribeira das Naus, em 1647. A estabilidade pós-guerra, que teve paz assinada em 1668, 
conduz à criação de um Corpo de Engenheiros do Reino (1695) e a aulas de Fortificação entre 1694 e 1701, que suprem a inexistência de ensino universitário nesta área e que funcionarão em Viana do Castelo, Bahia e Maranhão. Em 1732 organiza-se uma Academia Militar de Corte, e os saberes da engenharia são aí incorporados. Desta acumulação de possibilidades de divulgação de saberes e destas sucessivas incorporações institucionais, a que ainda se poderiam juntar as Academias de Engenharia, bem como sessões e classes de engenharia que decorrem em algumas outras Academias dispersas pelo Reino, nascem agentes deste saber que irão marcar o sistema e as formas de edificação das fortificações, mas e também, a arquitectura civil e urbanística de âmbito estético-conjuntural próprio das Luzes. Conhecemos muitos dos nomes daqueles que se afirmaram neste ofício-saber: Manuel de Azevedo Fortes, Manuel da Maia, Manuel Pinto Vila-Lobos, José Fernandes Pinto Alpoim, Diogo Silveira Veloso, Eugénio dos Santos, Carlos Amarante, José Sande de Vasconcelos, Reinaldo Oudinot, Guilherme Elsden e outros. Cidades em renovação por crescimento, moda ou em resultado de guerra ou cataclismos, fortes de fronteira em espaços imensos do Brasil-Colónia (Rio de Janeiro, Minas Gerais, Nordeste e interior do Brasil), construtores de cálculos e de geometrias sobre o real, todos eles se constituíram em parte individual de uma nova ordem social fundada em saberes e não em privilégios ou níveis de riqueza.

Mais casos como o dos engenheiros-militares? Os cirurgiões, quantas vezes tidos por charlatães, por oposição aos médicos escolásticos. Os juristas, melhor, os detentores de saberes em direito e retóricas, mas com exercício de confronto com a realidade como juízes-de-fora, corregedores de comarcas, desembargadores, alguns secretariados de Juntas, Mesas ou Embaixadas. Outros? Talvez outros, mas poucos serão.

Esta autonomia social perante ordens e estados era evidente a António Ribeiro dos Santos; por isso, ao ter de adequar modelos sociais e fundamentações intelectuais e ideológicas da sociedade para a qual queria legislar ou actuar, viu-se obrigado à sua leitura compreensiva e determinativa.

Num dos parágrafos de A verdadeira religião christã, de 1787, irá escrever:

o bem da sociedade, fundado principalmente na ordem, demanda que cada um dos membros, de que ela se compõe, desempenhe exactamente a parte que lhe toca neste grande corpo. O pai de família deve cuidar na educação de seus filhos, no estabelecimento de uma fortuna correspondente à sua qualidade, que seja adquirida sem avareza nem usurpação. 0 magistrado deve ser fiel executor das leis dadas pelo príncipe, sem se torcer por algum respeito humano. O soldado deve seguir exactamente as ordens dos seus superiores, defender intrepidamente a pátria e arriscar a vida quando a necessidade o pedir. O comerciante deve administrar cuidadosamente o seu negócio; o artífice trabalhar no seu ofício. Numa palavra, todos os membros da república, subordinados à lei do príncipe, devem satisfazer exactamente as obrigações dos seus respectivos estados, sem ofensa nem prejuízo dos demais. (In Pereira 1983, 211-212)

Onde estão as ordens que o rodeiam e que as leis do Reino ainda vêm consagrando? Onde estão os estados que, desde a configuração de D. Duarte no Leal Conselheiro (1438?), se têm como determinantes da constituição da Sociedade? Onde está a república e os cidadãos que se vêm almejando e que, passados dois anos, em Paris, os intérpretes políticos procurarão passar a escrito, depois das imposições e vitórias de rua? A cedência à organicidade como forma organizativa é da maior evidência, a começar, como sempre, pela família, pela autoridade constitutiva e fundadora do pai de familia; depois, o corpo que o magistrado representa, o daqueles que devem ser fiel executor das 
leis dadas pelo príncipe, ou ainda a força de legitimação do soldado, congregando toda a casta militar, em afirmação, e, por fim, a gente da riqueza, o comerciante e o artífice. De todos eles não se espera já, como diria no tempo de seiscentos D. Francisco Manuel de Melo, "que cada um esteja no seu lugar", mas que satisfaçam, cumpram exactamente as obrigações dos seus respectivos estados; só assim serão membros da república.

Os membros da república não o são por serem naturais da terra, ou vassalos do senhor príncipe, nem por isto ou aquilo, mas por deterem um saber ou uma capacidade de produzir, que com eles não nasceu, mas que lhes foi ensinado e que eles aprenderam em seu benefício (lucro) e da república; são por isso cidadãos.

Formar cidadãos... mas já todos eram vassalos? Na diversidade de gentes tutelada pelo Rei de Portugal, para a qual o legislador deveria trabalhar, nem todos assim eram considerados. Um outro limite... Com os anos de setecentos corria uma construção de sociabilidades urbanas, de leituras e de colecções, o mesmo será dizer de agentes leitores e coleccionadores. Esse modo e atitude de cultura fazia desses vassalos potenciais cidadãos e efectivos lutadores da cidadania. António Ribeiro dos Santos passava, ou sabia da existência desta atitude e conhecia muitos dos seus adeptos. Mas como se integrava ou dava corpo a essa realização?

Talvez que um caso de permeabilidade e de manutenção de práticas, conceitos e pesos de autoridade com visão de vassalagem e não de cidadania, exemplar em todos estes tópicos, seja o Directorio que se deve observar nas povoaçoens dos indios do Pará, e Maranhaõ, Em quanto Sua Magestade naõ mandar o contrario, impresso em Lisboa na Officina de Miguel Rodrigues, cuidadosamente classificado como Impressor do Eminentissimo Senhor Cardial Patriarca, em 1758. As transformações descritas pelo Directorio davam continuidade a outras duas leis de 1755: a primeira restituía a liberdade aos índios, e a segunda retirava aos missionários o poder temporal sobre as aldeias. Essas leis já continham o tom que teria o Directorio, diminuindo o poder dos religiosos sobre os índios (principalmente os jesuítas, que seriam expulsos em 1759) e promovendo mudanças nas relações entre índios e não índios.

\section{Escreve-se no parágrafo 3 do Directorio:}

Naõ se podendo negar, que os Indios deste Estado se conserváraõ até agora na mesma barbaridade, como se vivessem nos incultos Sertoens, em que nascêrão, praticando os pessimos, e abominaveis costumes do Paganismo, naõ só privados do verdadeiro conhecimento dos adoraveis mysterios da nossa Sagrada Religiaõ, mas até das mesmas conveniencias Temporáes, que só se podem conseguir pelos meios da civilidade, da Cultura, e do Commercio: E sendo evidente, que as paternáes providencias do Nosso Augusto Soberano, se dirigem unicamente a christianizar, e civilizar estes até agora infelices, e miseraveis Póvos, para que sahindo da ignorancia, e rusticidade, a que se achaõ reduzidos, possaõ ser uteis a si aos moradores, e ao Estado: estes dous virtuosos, e importantes fins, que sempre foi a heroica empreza do incomparavel zelo dos nossos Catholicos, e Fidelissimos Monarcas, seraõ o principal objecto da reflexaõ, e cuidado dos Directores. (Directorio 1758, 2)

74 De acordo com este regimento de actuação da política de Pombal, as aldeias deveriam ser transformadas em vilas e lugares com nomes portugueses administrados por um governo civil, o referido Director. As acções descritas ao longo dos artigos do Directorio deixam claro o objectivo de "assimilar", ao incentivarem a presença de não índios nas aldeias ou os casamentos interétnicos, que estimulavam a mestiçagem. O Directorio assegurou a liberdade aos índios ou extirpou os costumes indígenas? E como? 
Escolarizando, ou melhor, propondo regras de escolarização. Que regras? Uma escola por aldeia, com um mestre para os meninos e outro para as meninas; a proibição do uso de outra língua que não o português, nomeadamente da língua "do Brasil" (conhecida como tupi ou língua geral); a obrigatoriedade de cada índio ter um sobrenome português; a proibição da nudez e das habitações colectivas; como conclusão, a punição com a pena de morte a quem desacatasse o Directorio. Procurava-se com estas normas legislativas de Lisboa incorporar o índio na sociedade dos brancos, transformá-lo num trabalhador activo, para a Coroa e para os interesses dos grupos económicos, ao mesmo tempo que se asseguravam o povoamento e a defesa do território colonial brasileiro. Foi a forma encontrada para gerar "assimilação", um meio de transformar estes grupos em vassalos subordinados ao Rei de Portugal. Ainda em 1758, o Directorio sobre as povoaçoens dos indios do Pará, e Maranhaõ foi estendido ao resto do Brasil e, em 1798, foi revogado, tendo os índios aldeados nesta data sido legalmente emancipados e equiparados aos outros habitantes do Brasil (Domingues 2000; Xavier \& Silva 2016).

Aqueles vassalos-cidadãos, à procura de igualdade perante a lei compilada para cartilha do Reino-Estado, têm como seus iguais, ciganos, homens escravos africanos e índios? 0 entendimento social permitia e admitia reflexões... mas as práticas, ainda que só legislativas, o que incorporam de permanências e de mudança? Faça-se a releitura do texto citado do Directorio.

76 A primeira justificação que ali aparece resulta de uma manifestação de memória já bem firmada na cronística medieval sobre a dita "Reconquista" e que foi depois repetida sucessivamente pelos cronistas e missionários do avanço imperial de conquista e de exploração desde a costa de África ocidental ao Brasil: as populações locais, aqui os índios, vivem na barbaridade praticando o Paganismo e estão privados do verdadeiro conhecimento dos adoraveis mysterios da nossa Sagrada Religiaõ. Tópicos convencionais do cruzadismo expansionista. Mas repare-se na frase seguinte; algo de novo aí surge, um novo campo de justificação, mas altera-se o fim? Escrever que os índios com este seu viver estão privados até das mesmas conveniencias Temporáes, que só se podem conseguir pelos meios da civilidade, da Cultura, e do Commercio, contém alguma alteração em relação a estes vassalos do Rei, ou simplesmente altera-se o olhar europeu que se lhes lança? o legislador admite o campo da Sagrada Religiaõ, vai mantê-lo por reconhecimento temporal de memória, como fez Verney, e acrescenta-lhe as suas preocupações de civilidade, com dois outros marcadores: Cultura e Commercio.

77 A lógica de centramento mantém-se; estes vassalos, que assim devem ser considerados, vão beneficiar daquilo sobre que o Nosso Augusto Soberano vem legislar: christianizar, $e$ civilizar. Educar, disciplinar, inculcar. Tudo justifica a acção sobre estes até agora infelices, e miseraveis Póvos que os fará sair da ignorancia, e rusticidade, passando a vir a ser uteis a si e aos outros moradores do Pará e Maranhão.

O vocabulário é muito expressivo; a saída da ignorância lembra de imediato Kant no seu texto de 1784 de resposta à pergunta sobre o que são as Luzes (cfr. Pereira 1984), entre outros de jornais, Academias e polémicas de publicistas que já mereceram estudos alargados e sistemáticos (Gusdorf 1971; Gusdorf 1972; Pereira 1990, v. I: 273-302; Foucault 2007; Badinter 2011). O que se escreve é um bom exemplo da nova semântica das Luzes. E a prática sociopolítica que lhe subjaz ou que daí recrudesce? E o poder tutelar e as normas do Nosso Augusto Soberano? Nosso! Não é despicienda a palavra, é um possessivo comum, uma afirmativa de uma comunhão de interesses e fins de assumir a 
corporatividade do Reino, consignada nas ordens e seus privilégios, nas clientelas e "vassalidades" que se querem convergentes num só centro.

Onde estão os cidadãos? Onde se ultrapassam as leis tão simples e rigorosas, mas de matriz cortesã e elitista, como a Ley porque se determinaõ os tratamentos, que se devem usar nestes Reynos, e Senhorios de Portugal, de 1739 (Provas 1950, t. IV: 383-387)?... O impressor do Directorio, Miguel Rodrigues, é, como se escreveu, Impressor do Eminentissimo Senhor Cardial Patriarca; D. Frei Manuel do Cenáculo, como destinatário das epístolas do doutor António Ribeiro dos Santos, ainda que em 1796 ou em 1808, é sempre Excelentissimo e Reverendissimo Senhor e no corpo das mesmas, sempre, Vossa Excelencia ${ }^{4} . .$. Alei cumpriuse... Os poderes do Rei afirmam-se, mas limitam-se com o crescimento das estruturas da administração e das justiças. Um instituto jurídico, que se vai tornando distinto, ganha e afirma-se sob a designação de Estado. Como escreveu Ribeiro dos Santos, o Estado não é nem pode ser um património; pois que o património é feito para bem do senhor, quando o príncipe é estabelecido para bem do Estado (in Pereira 1983, 310). Muito claro, é uma definição segura da relação de poderes Príncipe/Estado para garantir as permanências e permitir a mudança.

Clara é ainda a apreciação que António Ribeiro dos Santos faz das práticas e lógicas de poder e de cultura do Marquês de Pombal, as quais descreveu a um destinatário anónimo:

Este ministro quis um impossível político; quis civilizar a nação e ao mesmo tempo fazê-la escrava; quis espalhar a luz das ciências filosóficas, e ao mesmo tempo elevar o poder real ao despotismo; inculcou muito o estudo do direito natural e das gentes e do direito público universal, e lhes erigiu cadeiras na Universidade de Coimbra, mas não via que dava luzes aos povos para conhecerem por elas o que o poder soberano era unicamente estabelecido para o bem comum da nação e não do príncipe, e que tinha limites e balizas em que se devia conter. (Dias 1975, t. 14: 447)

Os privilégios e excepções sentem o crescimento do Estado, que vive das leis, perante as quais, cada vez mais, todos se querem iguais. Os corpos de saber e de especular consagrados nos diferentes direitos opõem-se, anulam-se. As leis afirmam-se, fugindo ao privilégio e à pertença a corpos sociais.

Em todas estas permanências, mudanças, configurações e reconfigurações, há políticas económico-sociais e de cultura. Nelas pode ver-se o desenho de intelectual do Doutor António Ribeiro dos Santos; mas como observá-lo e tentar a sua compreensão? Do que até aqui se escreveu, uma introdução generalista e ainda pouco sólida, resultam duas linhas a explorar, conclusões parciais, se se quiser.

83 A primeira é a constante duplicidade do uso de palavras e de conceitos que é muito significativa deste pensar do Barroco nas Luzes. A última passagem epistolar citada, de apreciação à acção pombalina, é um exemplo acabado. As palavras e os seus conteúdos digladiam-se, procuram impor-se ou são revistos nos seus significados. Faça-se uma lista: civilizar, nação, luz e luzes, ciências filosóficas, poder real, despotismo, direito natural edasgentes, gentes e povos, poder soberano, bem comum, nação. Ao longo do texto todas elas se tornaram evidentes na construção da sociedade e dos poderes por António Ribeiro dos Santos. Os pares Reino/Estado, Príncipe-Rei/Estado, vassalos/cidadãos, Reino/ Pátria, Reino/Nação assumem a dianteira no uso escrito ou na pressuposição resultante da análise documental.

Talvez que em António Ribeiro dos Santos o que mais tenha mudado, não permanecido, seja o sistema de discurso e de suporte vocabular. Nota-se sucessivamente um 
crescimento de racionalidade compositiva e de palavreado das Luzes. Ainda que o seu fundo descritivo seja de permanências ou de criação de disfunções orientadas para um ideário enciclopédico e pós-Revolução Francesa, o discurso é abertamente racionalizante, o que se evidencia, nomeadamente, nas construções de normativa jurídica ou na criação de orgânicas e classificações de bibliotecas (Ferreira 2011, 115-131).

A segunda é permanente e, muitas vezes, tão afirmativa e envolvente que se perde para o investigador. Foi o que aqui aconteceu. A razão, enquanto lógica argumentativa e referente de cultura e de saber, devia ter sido mais presente neste inquérito. Assinalese a sua presença constante, submersa ou aflorada, e a sua quase ausência neste estudo. Passe-se a palavra a António Ribeiro dos Santos e deixe-se encerrar o texto com uma sua explicação sobre o papel da razão nas permanências e mudanças:

A razão é clara. Contingente é todo aquele ente que depende de outro para a sua existência e conservação. Logo, a causa última de todos os contingentes não pode ser um contingente, pois que este ainda vinha a depender de outro para existir; mas deve precisamente ser um ente necessário, o qual subsista por si mesmo e sem dependência de alguém. (In Pereira 1983, 208-209).

\section{BIBLIOGRAFIA}

ANDRADE, António Alberto de. 1966. Vernei e a Cultura do seu Tempo. Coimbra: Universidade de Coimbra. ARAÚJO, Ana Cristina. 2003. Modernidade cultural e mentalidade barroca. A Cultura das Luzes em Portugal. Temas e problemas. Lisboa: Livros Horizonte.

BADINTER, Élisabeth. 2011. Les Passions intellectuelles. I. Désirs de gloire (1735-1751), II. Exigence et dignité (1751-1762). III. Volonté et pouvoir. Paris: Fayard.

BECKFORD, William. 1997. Alcobaça e Batalha. Recordações de viagem, ed. Iva Delgado, Frederico Rosa. Lisboa: Vega.

BRAGA, Isabel M. R. Mendes Drumond. 2005. Os almanaques portugueses no século XVIII. Cultura, Religião e Quotidiano. Portugal (século XVIII). Lisboa: Hugin.

BRIGOLA, João Carlos Pires. 2003. Colecções, Gabinetes e Museus em Portugal no Século XVIII. Lisboa: Fundação Calouste Gulbenkian/FCT.

CARAPINHA, Aurora. 1985. Inventário da Arte Paisagista em Portugal: Trabalho de síntese. Provas de Aptidão Pedagógica e Capacidade Científica apresentadas à Universidade de Évora.

CARAPINHA, Aurora. 2011. País enquanto paisagem. Revista da Associação dos Arquitectos Paisagistas 5: 20-26.

CARDOSO, José Luís. 1997. Viagens filosóficas e mapas económicos: a redescoberta do espaço social nos finais do século XVIII. Pensar a Economia em Portugal. Digressões históricas, 101-118. Lisboa: Difel.

CASTRO, João Baptista. 1768. Roteiro Terrestre de Portugal... Lisboa: Miguel Manescal da Costa. 
CENÁCULO, D. Frei Manuel do. 2014. "Até cair da mão a pena". In Epistolário de Ribeiro dos Santose Frei Manuel do Cenáculo, 1796-1808, pesquisa e introdução Manuela Domingos. Lisboa: Biblioteca Nacional de Portugal.

CORTESÃO, Jaime. 1984. A cultura da longitude e a formação dum novo tipo social. Alexandre de Gusmão e o Tratado de Madrid, 349-383. Lisboa: Livros Horizonte.

CORTESÃO, Jaime. 1984. Alexandre de Gusmão e o Tratado de Madrid. Lisboa: Livros Horizonte.

COSTIGAN, Arthur William. 1989. Cartas sobre a Sociedade e os Costumes de Portugal, 1778-1779, 2 vols. Lisboa: Lisóptima.

COURA, Inocêncio Fernandes. 1731. Método da agricultura. Almanach Lusitano do anno de 1732, bissexto. Lisboa Ocidental: Oficina de António Pedroso Galrão.

DARNTON, Robert. 2013. L'Aventure de l'Encyclopédie (1775-1800). Un best-seller au siècle des Lumières. Paris: Éditions du Seuil.

DIAS, Luís Fernando de Carvalho (ed.). 1975. Algumas cartas do Doutor António Ribeiro dos Santos aos seus contemporâneos. Revista Portuguesa de História 14: 413-519.

Directorio que se deve observar nas povoaçoens dos indios do Pará, e Maranhaõ, Em quanto Sua Magestade naõ mandar o contrario. 1758. Lisboa: na Officina de Miguel Rodrigues.

DOMINGUES, Ângela. 2000. Quando os Índios Eram Vassalos: colonização e relações de poder no Norte do Brasil na segunda metade do século XVIII. Lisboa: CNCDP.

FERREIRA, Jorge M. Rodrigues. 2011. História da Biblioteconomia em Portugal (c. 1740-1926). Lisboa: Caleidoscópio.

FERRO, João Pedro. 1995. A População Portuguesa no Final do Antigo Regime (1750-1815). Lisboa: Presença.

FONSECA, Fernando Taveira da. 2000. Demografia eclesiástica. II. Do século XVI aos inícios do século XX.

Dicionário de História Religiosa de Portugal, vol. C-I, 47-59. Lisboa: Círculo de Leitores.

FOUCAULT, Michel. 2007. Sobre la Ilustración, ed. Javier de la Higuera. Madrid: Tecnos.

GOMES, Joaquim Ferreira. 1989. O Marquês de Pombal criador do ensino primário oficial. Duas listas de professores: uma elaborada pelo governo do Marquês de Pombal e outra pelo de D. Maria I. O Marquês de Pombal e as Reformas do Ensino, 9-26, 27-75. Coimbra: INIC.

GORANI, Giuseppe. 1989. Portugal. A corte e o país nos anos de 1765 a 1767. Lisboa: Lisóptima.

GOUVEIA, António Camões. 1998. Educação e aprendizagens. Formas de poder na paideia do Portugal moderno. Ler História 35: 11-44.

GUSDORF, Georges. 1971. Les Principes de la pensée au siècle des Lumières. Paris: Payot

GUSDORF, Georges. 1972. Dieu, la nature, l'homme au siècle des Lumières. Paris: Payot.

LIMA, D. Luís Caetano de. 1735. Geographia de todos os estados soberanos de europa. Tomos I e II, Em que se tracta de Portugal. Lisboa: José Antonio da Silva.

MERVEILLEUX, Charles Fréderic de. 1983. Memórias instrutivas sobre Portugal, 1723-1726. 0 Portugal de D. João V Visto por Três Forasteiros, 129-257. Lisboa: Biblioteca Nacional.

MOREIRA, Rafael. 1989. Engenharia militar. Dicionário da Arte Barroca em Portugal, 155-159. Lisboa: Presença. 
NETO, Maria João. 1997. James Murphy e o Restauro do Mosteiro de Santa Maria da Vitória no século XIX. Lisboa: Estampa.

NUNES, Maria de Fátima. 2001. Imprensa Periódica Científica (1772-1852): Leituras de "sciencia agricola" em Portugal. Lisboa: Estar.

PEREIRA, José Esteves. 1983. O Pensamento Político em Portugal no Século XVIII. António Ribeiro dos Santos. Lisboa: IN-CM.

PEREIRA, José Esteves. 1984. Kant e a "Resposta à pergunta: o que são as Luzes". Revista Cultura. História e Filosofia 3: 153-168.

PEREIRA, José Esteves. 1990. As ideias do século. Portugal Contemporâneo, coord. António Reis, vol. I, 273-302. Lisboa: Alfa.

Provas da história genealógica da Casa Real Portuguesa. 1950. Ed. António Caetano de Sousa, nova edição revista de M. Lopes de Almeida e César Pegado. Coimbra: Atlântida.

SERRÃO, Joaquim Veríssimo (ed. e introd.). 1970. A População de Portugal em 1789. 0 censo de Pina Manique. Lisboa: Fundação Calouste Gulbenkian.

SERRÃO, José Vicente. 1994. O quadro humano. História de Portugal. o Antigo Regime (1620-1807), coord. António Hespanha, vol. IV, 49-69. Lisboa: Círculo de Leitores.

SILVA, Ana Cristina Nogueira da. 1998. O Modelo Espacial do Estado Moderno: Reorganização territorial em Portugal nos finais do Antigo Regime. Lisboa: Estampa.

TELLES, Gonçalo Ribeiro. 2003. A Utopia e os Pés na Terra. Lisboa: IPM.

TOURS, François de. 1989. Itinerário em Portugal, 1699. Portugal nos Séculos XVII e XVIII. Quatro testemunhos, 47-53. Lisboa: Lisóptima.

VERNEY, Luís António. 1949. Verdadeiro Método de Estudar, ed. António Salgado Júnior, 5 vols. Lisboa: Livraria Sá da Costa.

XAVIER, Ângela Barreto, e Cristina Nogueira da Silva (org.). 2016. O Governo dos Outros. Poder e diferença no Império português. Lisboa: ICS.

\section{NOTAS}

1. Todos os dados numéricos foram recolhidos em Serrão 1970, XI-XXX. Cf. Ferro 1995; Serrão 1994.

2. Na reedição, em 4 volumes, pela Livros Horizonte: Cortesão 1984, 483-788.

3. Seguem-se, parafraseando, no sentido da leitura de conjuntura intelectual que aqui se procura, os conteúdos do estudo de João Brigola.

4. Cenáculo 2014, 29, 43, 45, 49, 51, 55, 57, 59, 63, 65, 67, 72, 70, 76, 78, 79, 83, 84, 85, 87, 88, 90. 


\section{RESUMOS}

Os tempos conjunturais de 1745 a 1818 são, tal como a vida e actuação de António Ribeiro dos Santos, diversificados e dissonantes. Qual o problema de fundo deste artigo? Tentar retraçar e compreender as linhas de um desenho, de componente biográfico-intelectual, em que as cores da paleta do barroco atlântico-joanino paulatina mas persistentemente se tornam mutáveis em luzes enciclopédicas e europeias. O Reino estendia-se em paisagens de senhorios e concelhos, pontuadas por uma rede crescente de espaços urbanos em extensões de império atlântico e olhadas intermitentes ou dependentes da Europa. Os poderes do rei afirmavam-se, mas limitavam-se com o crescimento das estruturas da administração e das justiças. Um instituto jurídico, que se ia tornando distinto, ganhava e afirmava-se sob a designação de Estado. Os privilégios e excepções sentiam o crescimento do Estado, que vivia das leis, perante as quais, cada vez mais, todos se queriam iguais. Nas paisagens, sujeitos àqueles poderes, viviam vassalos. Vassalos que eram uma das preocupações da época.

The figure of Antonio Ribeiro dos Santos (1745-1818) may be studied not merely as a direct influence in the reshaping of the Portuguese State and its Atlantic/imperial possessions but his work as an embodiment/reflection of a wider European enlightenment critique of the existing structures of power. All of this may be seen in the creation of administrative and legal institutions, that while emerging from and dependent on the continuation of regal authority, also extend the role of the State as such in diminishing/removing the customary privileges and exceptions of the landowning classes. This has the effect of moving towards a greater social parity and equality before the law, and the eventual modification of the earlier state of vassalage in a distinctive Portuguese response to the era of the American and French revolutions.

\section{AUTOR}

\section{ANTÓNIO CAMÕES GOUVEIA}

CHAM e DH, FCSH, Universidade Nova de Lisboa; CEHR, Universidade Católica Portuguesa,

Portugal. acamoesgouveia@gmail.com

Licenciado em História, pós-graduado em História Cultural e Política e doutorado em História e Teoria das Ideias, especialidade em História das Ideias Sociais, pela NOVA FCSH. Nessa mesma Faculdade dá aulas desde 1981. Investigador do CHAM - Centro de Humanidades (NOVA FCSHUAc) e do Centro de Estudos de História Religiosa (UCP). Esteve em Comissão de Serviço entre 1992 e 1997 na Comissão Nacional para a Comemoração dos Descobrimentos Portugueses, e de 2010 a 2012 como director do Museu de Évora. De 2004 a 2013 foi Coordenador Científico da Fundação Robinson, em Portalegre. As suas áreas de interesse científico centram-se na História Social, das Sociabilidades e dos Poderes nas vertentes da História da Cultura, das Mentalidades e da História Religiosa. Em confluência teórico-prática junta-lhes a Programação de Cultura, nas dimensões do Património, da Museologia e da Mediação.

Bachelor of History, postgraduate in Cultural and Political History and PhD in History and Theory of Ideas, specializing in History of Social Ideas, by NOVA FCSH. In this same Faculty he has taught since 1981. Researcher at CHAM - Centre for the Humanities (NOVA FCSH-UAc) and the Center for the Study of Religious History (UCP). He was in Service Commission between 1992 and 1997 in the National Commission for the Commemoration of the Portuguese Discoveries and from 2010 to 2012 as director of the Museum of Évora. From 2004 to 2013 he was Scientific Coordinator of the 
Robinson Foundation, in Portalegre. His areas of scientific interest focus on Social History, Sociabilities and Powers in the strands of the History of Culture, Mentalities and Religious History. In theoretical-practical confluence, they are associated with Cultural Programming in the dimensions of Heritage, Museology and Mediation. 